\title{
The Influence of External Stimuli on Impulsive Buying Behaviour
}

\author{
DR. SYED HAIDER KHALIL \\ Assistant Professor, Institute of Business Studies and Leadership \\ Abdul Wali Khan University Mardan \\ ALI RAZA \\ MS Research Scholar, Institute of Business Studies and Leadership \\ Abdul Wali Khan University Mardan
}

\begin{abstract}
The aim of current study is to critically examine impulse buying behaviour of customers through the lens of external stimuli. The current study provides a plethora of evidences to extend our knowledge about the behavioural aspects of consumers and key factors of buying decision. The current study looked into External Stimuli through sub factors such as Store Environment, Income Level, Window Display, Credit Card and Visual merchandising to examine their significance on impulse buying. For finding the correlation and interconnectedness of impulsive buying with the above-mentioned factors, we collected primary data through questionnaire survey, which was then analysed using quantitative analysis method. The findings of our study suggest that Store Environment and Income level are highly influential on impulsive buying behaviour whereas the use of credit card has the least impact on impulsive buying behaviour.
\end{abstract}

Key words: Impulse Buying Behaviour, Consumers, External Stimuli, Pakistan, Purchase Patterns, Behavioural Changes.

\section{Introduction}

The word 'impulse' refers to a sudden, strong and unreflective desire to act thus impulse buying suggest customers buying behaviour without prior intention to purchase. In marketing world, 'impulse buying' is a well-recognized phenomenon and has a high ratio of impulsive buying as evident from the findings of the United States of America (USA) customers who purchased magazines and chocolates (Gelitz, 1995). According to an estimate, $80 \%$ of purchase decision are influenced by impulsive buying (Weigend, 1995). Impulsive buying is an unexpected and unreflective behaviour, which neglects a careful consideration of the facts to choose a product (Kacen \& Lee, 2002). Impulse purchasing remained considerably well research phenomenon in the last five decades where researchers highlighted and extended our understanding of key factors influencing impulse buying behaviour (Jalees, 2009). Prior studies reveal that impulse buying behaviour evolved from earlier concepts such as 'Impulsive purchasing' or 'Spontaneous or unplanned purchasing', and the common theme in these concepts is that buyer, when entering the store, did not have any rational thoughts of buying a specific product, yet they have made frequent purchases (Kollat \& Willett, 1969).

Evidently, this phenomenon is commonly termed as impulse purchasing and became a key point of research in academia to examine key factors and other related issues (Jalees, 
2009). Prior studies have been attempted to examine impulse purchasing behaviour and key influencing factors, however; majority of these studies were conducted in the United States and other Western Countries (Jalees, 2009) and there is paucity of research in understanding the significance of these factors in less developed countries such as Pakistan. In the last six decades, the meaning and understanding of impulse buying behaviour kept on evolving where the definition, influencing factors, and new insights have been added to the existing body literature (Karbasivar \& Yarahmadi, 2011). Steinberg, Vishnu, \& Raheem (2013) looked into the factors from outward and input perspective. They argued that outward factors such as product's show prompts impulse buying and celebrity indorsing mostly has effect on youngsters and young grown-ups. Inward factors include customer's attributes that inferred the expanding level of impulse buying, examples of internal signs are expresses of one's mental connections, client's regularizing appraisal of expanding obtaining engagement and statistic factors like demographics (Kacen \& Lee, 2002).

Ahmad (2016) argued about the behavioural changes by looking into the of retail sector of Pakistan, which suggested that the sector has evolved dramatically as a consumer lifestyle continues to change with the improving economy, purchasing power and the growing consumer demand in the country. This change has become more prominent in the large metropolitan cities where hypermarkets or supercentres are making inroads into the developing retail sector of Pakistan. In return, the retail sector makes a huge contribution to the overall economic activity of the country. Evident from the data of Pakistan Bureau of Statistics (PBS) for 2011-12, the retail sector is worth 4.2 billion dollars that accounts for approximately 18\% of Pakistan's GDP for the period 2007-2012. When we looked into the private sector for the period 2007-2012, we can notice an enormous surge, about $130 \%$ increase, in the consumption even with the relatively slow growing GDP during this period. This implies that understanding the purchase patterns, especially the impulse buying behaviour, became highly significant in the growing retail sector of Pakistan.

Conducting a research about impulse buying behaviour in Pakistan, can contribute both to academia and to the context: for academia, it will contribute to our understanding about Pakistani retail market by emphasising the role of impulse buying behaviour and its interconnected factors, and for Pakistani market, it may provide practical useful insights about retail business and purchase patterns that can potentially benefit the retailers, marketing managers and other strategic decision makers in Pakistan. In this sense, the current study adopts a pragmatic approach to the research problem related to impulsive purchasing behaviour and external factors in Pakistan that can be empirically tested in future research assignments. A recent study by Ahmad and Parmar (2013) argued that the impulsive buying behaviour is influenced by different factors. They characterized these factors into four different categories such as Internal Stimuli, External Stimuli, Sociocultural factors and Situational factors. They further focused on external factors and characterized them as store environment, income level, window display, credit card and visual merchandising. The aim of our study is to build on their findings by critically examining the sub-factors of external stimuli and its impact on impulsiveness of a customer's buying nature in retail market of Pakistan. This led to the development of 
objectives for the current study, which is two-fold: first, to examine the influence of external stimuli on impulsive buying behaviour and second, to examine the influence of sub-factors of external stimuli on impulsiveness.

\section{Literature Review}

Impulsive buying has been widely debated among researchers and can be traced back to early 1960s (Clover, 1950; Peck \& Childers, 2006; Rook, 1987; Stern, 1962). Abratt and Goodey (1990) argued that the findings from prior studies on impulsive buying in different retail markets seems highly significant to the marketers and retailers. Piron (1991) further characterised impulsive buying by looking into the secondary sources of data and argued that prior researches revealed impulsive purchasing are highly limited and became difficult to distinguish this concept from a basic understanding of spontaneous buying (Clover, 1950; West, 1951), and suggested an in-depth investigation for impulsive buying and its related factors. With the increasing interest in impulse buying pattern, several studies, for instance (Beatty \& Elizabeth Ferrell, 1998; Piron, 1991; Rook, 1987), were attempted to conceptualise, understand, and define impulsive purchasing and its key influential factors (Jalees, 2009). The subsequent section highlights the main contributions made by the prior studies about the concept of impulsive buying.

\subsection{Impulse Buying}

An investigation of buying behaviour forces, Rook and Hoch (1985) found that indiscreet customers have a tendency to appreciate shopping more than the individuals who are more wary in their purchasing styles. Gender contrasts likewise exist, as females in the investigation delighted in shopping more than guys and had a tendency to be more incautious. This sexual orientation distinction in buyer impulsivity could incompletely reflect the way that men and ladies regularly look for different kinds of items and have diverse shopping inspirations. In a similar way, Hoch and Loewenstein (1991) argued that impulsive buying as a fight between the psychological forces of wants and resolve. Recreational customers, similar to customers persuaded by hedonic esteems, are more averse to have a thought of what they will purchase when they go shopping, which proposes more noteworthy levels of motivation obtaining, and they invest more energy shopping by spending more time in store (Bellenger \& Korgaonkar, 1980).

A study conducted by Rook and Gardener (1993) contended impulse buying is spontaneous which doesn't involve a rational thinking. It is an unplanned decision leading to possession of a good. Almost the same phenomenon was concluded by Beatty and Ferrell (1998) as impulse buying lacks objective or prior planning of a person to buy a good for a specific need. They further said that impulsive buying behaviour doesn't include any second thoughts in-fact it is a result of a sudden desire of possession of a certain thing. Bayley and Nancarrow (1998) characterised impulsive purchasing as an unexpected, convincing, hedonically complex purchasing conduct in which the speed of motivation decision process blocks sharp and considering thoughts for choice information and decision. Impulsive buying is something separate to the satisfaction rather than the utilitarian behaviour which includes the customers to search for helpful points of interest and money related motivating force in the shopping methodology. Another research study by Kacen and Lee (2002) debated that impulse buying are all the more energizing and 
effective but less thoughtful as compared to arranged buying conduct. Han, Morgan, Kotsiopoulos and Park (1991) altered Stern's (Stern, 1962) arrangement of impulsive blend as four types of factors that influence the impulsive purchasing conduct. The four types are planned impulse buying, reminded impulse buying, suggestion or fashion oriented impulse buying and pure impulse buying.

Bhakat and Muruganantham (2013) argued that the planned impulsive buying is somewhat desirable, but the client does not select any particular element or classes. They also decide on the prerequisite for achieving distinctive offers in the store. Reminded impulsive purchasing happens after a purchaser is recalled for the requirement for an item to be able to see it in the store. A pure compulsive purchase is an impulse purchase, which the client breaks the scheme of general purchases. Mattila and Enz (2002) later on argued about situated impulsive buying that when placing purchases, buyers can influence their own positive emotions. Babin and Babin (2001) argued that acquisition targets and shopper spending in stores can usually be affected by feelings. These feelings can be specific to specific things, for example, the main points, the client's own interests, the buyer's measure in what they value, and the value they provide for their purchase in the store.

\subsection{Factors Influencing Impulse Buying}

The impulsivity in the buying nature of a customer is influenced by several factors such as the store environment, buyer's personal traits, the buyer's demographics and sociocultural aspect and also by a product itself (Bhakat \& Muruganantham, 2013). Their study characterised the factors into four groups such as External Stimuli, Internal Stimuli, Situational and Product related factors and Demographics and Socio-cultural factors.

Bhakat and Muruganantham (2013) further argued that internal stimuli are something internal as it is related to different personality factors. The Inner components of the impulse purchase mean the inward attributes of a person that makes him participate in buying momentum. Shapiro (1992) argued that situational signs of impulse purchases include the location of the retail store, the time of purchase, the seasons and the forms of purchase. Impulsive buying behaviour is affected by the socioeconomics and other characteristics of a purchaser (Kollat \& Willett, 1969). Helga and Jane (1995) argued that as a social classification, gender affects impulse buying behaviour. Men tend to participate in impulsive purchases of instrumental and entertainment items that enhance their freedom and action. Women tend to buy symbolic and self-expressing objects related to their appearance and emotional characteristics. However, the current study focuses on the sub-factors of external stimuli such as store environment, window display, income level, credit card and visual merchandising and critically examine the influence of each sub-factor's effect on the impulsivity of the buyer.

\subsection{External Stimuli}

The outside variables of the impulsive purchasing behaviour refer to show signals and promotional supports which established and organized by marketers that tries to attract the customers towards a buying behaviour (Youn \& Faber, 2000). External stimuli are recognized with the purchases and terms of the showcasing. Terms of purchase include the measure of the store, the atmosphere, the plan and the configuration, while the 
condition of presentation are various offers and exercises to promote (Steinberg et al., 2013). The sub-factors of external stimuli are as follows.

\subsubsection{Store Environment}

The buying power can be triggered when the buyer is exposed to visual changes applicable in retail environment or special promotions (Piron, 1991). Expressive gestures refer to conditions identified with the number, sort, and behaviour of clients and representatives, and comparable qualities (Bitner, Ward, \& Barnes, 1992). They further argued that the physical condition of the store may evoke psychological, enthusiastic, and physiological reactions which will influence purchasers' approach or evasion conduct in the retailing setting. Parameters of retail stores influence the reaction of customers in the store and in the future selection of the store. The nature and the physical appearance of the store also has an effect on the choice of buyers for choosing a store (Underwood, Klein, \& Burke, 2001).

$\mathrm{Xu}$ (2007) argued that the situation in the store affects the passionate state of buyers, which can also stimulate the impulse purchase of the products in a store. Rook and Hoch (1985) argued that the motivation for buying starts with the sensation and recognition of the buyer caused by external stimuli and is caused by a sudden desire to buy. In the current situation, impulsive buying is appropriate for purchasing with imaginative offers, imaginative memos and the correct usage regarding advances in stores (Schiffman, Kanuk, \& Wisenblit, 2010).

\subsubsection{Income level}

Previous research suggests that in America, contrasting to the other countries of the world, the higher level of pay is one of several elements that represents an advanced phase of impulse buying (Abratt \& Goodey, 1990). Impulsive buying is considered predominant for buyers who can manage its value as the level of pays affects the behaviour of motivating buyers (L. E. Wells, Farley, \& Armstrong, 2007). The buyer, who needs to buy items, is subject to his salary. Buyers with a higher level of payment are less sensitive than buyers with lower wages, and buyers with higher wages generally take part impulsive buying behaviour (Butkevičienè, Stravinskienè, \& Rūtelionienè, 2015). As indicated by Xiao and Nicholson (2013), the income level is one of the key statistic factors impacting the non-spontaneous purchasing behaviour in retail showcases. They further took note of that the majority of the investigations in the past have reasoned that the level of pay is a key influencer of the shopper behaviour. On the other hand while checking on different experimental examinations, Wells, Parboteeah and Valacich (2011) proposed that the vast majority of the customer behavioural researchers have gone to an agreement that the social class is a key determinant of the purchasing behaviour. In any case, as clarified by Podoshen and Andrzejewski (2012), the social classes are recognized in light of the level of income.

\subsubsection{Window Display}

It is argued by Karbasivar and Yarahmaadi (2011) that window display may impact, in any event to some degree, buyers' decision from a store when they don't set out with a particular reason for going to a specific store and a specific thing. Most of the retailers are paying more attention to the showcasing of items to attract the attention of viewers and ultimately turn potential buyers into their customers (Madhavi \& Leelavati, 2013). 
About the "window show" as far as buyer's buying practice has a base consideration and thus, the viewpoint of the store impacts buyer's prior needs (Rettie \& Brewer, 2000). Kristina and Vilte (2008) argued that the frontal level creates an image for the basic need. This may indicate that this can affect customers at a certain level. Now the popularity of the "window show" is expanding to attract attention and ultimately change the potential customers to the buyers.

\subsubsection{Credit Card}

Karbasivar and Yarahmadi (2011) argued about the credit card that its usage will be built up by impulsive purchasing exercises. There is a request for the relationship between the purchase of an impulse and the use of a credit card because credit card is one of the best ways to purchase. Another researcher also argued that the use of credit card uncovers the purchaser's buying pattern with respect to expected purchasing while specialized technical developments makes rotating the credit extremely easy for credit supplier (Ampuero \& Vila, 2006).

Wang and Xiao (2009) argued that lacking social help may make the student take part in problematic conduct. Credit card administration is another subject to them. Some may make the credit card's purchasing power and acquiring flexibility yet don't know or ignore the potential results. The individuals who have satisfactory direction, recommendations and advices from their social communities are probably going to deal with their accounts effectively. For instance, they can find out about credit card premiums and punishments from a more experienced client and also they can likewise figure out how to deal with adjusts when they gather. A rotating balance on credit card, as small as it may be, may develop into a wild sum after some time. Those with almost no social help may stall out with their accounts and caught by the punishments of charge cards.

\subsubsection{Visual Merchandising}

Ahmad R.R and Parmar (2013) argued that visual merchandising is the strategy for arranging and organizing the items in a perfect order for highlighting the availability of the items in store for the customers. It is also called a visual presentation, its purpose is to inform retailers and companies about the quality, dignity and design of the mold. The commercialization of visual merchandising is to educate customers and increase the description of the store and company, as well as to increase the abundance of products and display them among themselves and other add-ons. (Silayoi \& Speece, 2007). Retailing outlets have a tendency to develop the overall picture of an outlet and represent the goods to their customers in a way that can attract their attention, which makes their decision without a doubt (Julie, Michael, \& Dhruv Grewal, 1992).

Visual merchandising is a compelling introduction of items that affects the clients to buy (Walters \& White, 1989). The presentation of a store and its stock to the customer through the cooperation of the store's promoting team, appear, remarkable events, plan coordination, and promoting divisions focusing on the true objective to offer the items and undertakings offered by store (Mills, Paul, \& Moormann, 1995). Retailers are slowly understanding that lone offering the item isn't critical, yet clients' fulfillment and comfort is additionally essential for shopping. Changes in retailing incorporates space related, item related and individuals related viewpoints (Quartier \& Jan, 2009). Visual 
merchandising incorporates both store outside and inside. The store outside incorporates window show, façade and retail premises. Window show is a medium which makes initial introduction in client's brain to enter the store. Physical allure of the store impresses the clients very for store choice (Darden, Erdem, \& Darden, 1983).

\section{Methodology}

\subsection{Research Design}

We earlier identified the research problem that led to the development of methodology for the current study. The current study looks in the relationship of two variables by drawing inferences thus aligns with the positivist approach at the philosophical level Saunders, Lewis, \& Thornhill, 2009). By adopting a positivist philosophy, the study therefore falls in realms of deductive approach (Saunders et al., 2009). The present study being a deductive and quantitative in nature which makes a survey method highly suitable for the collection of date. Our study is cross-sectional, which refers to the collection of data at a single point of time (Bashir, 2011).

\subsection{Parameters of Research}

The participants were selected randomly and were contacted in different shopping malls of Mardan. The profile of respondents varied at social, age, gender, educational and professional occupation level.

\subsection{Research Model}

Figure 1 shows the conceptual model of the variable.

\section{Figure 1}

\section{Conceptual Framework} Independent Variables

\section{Dependent Variable}

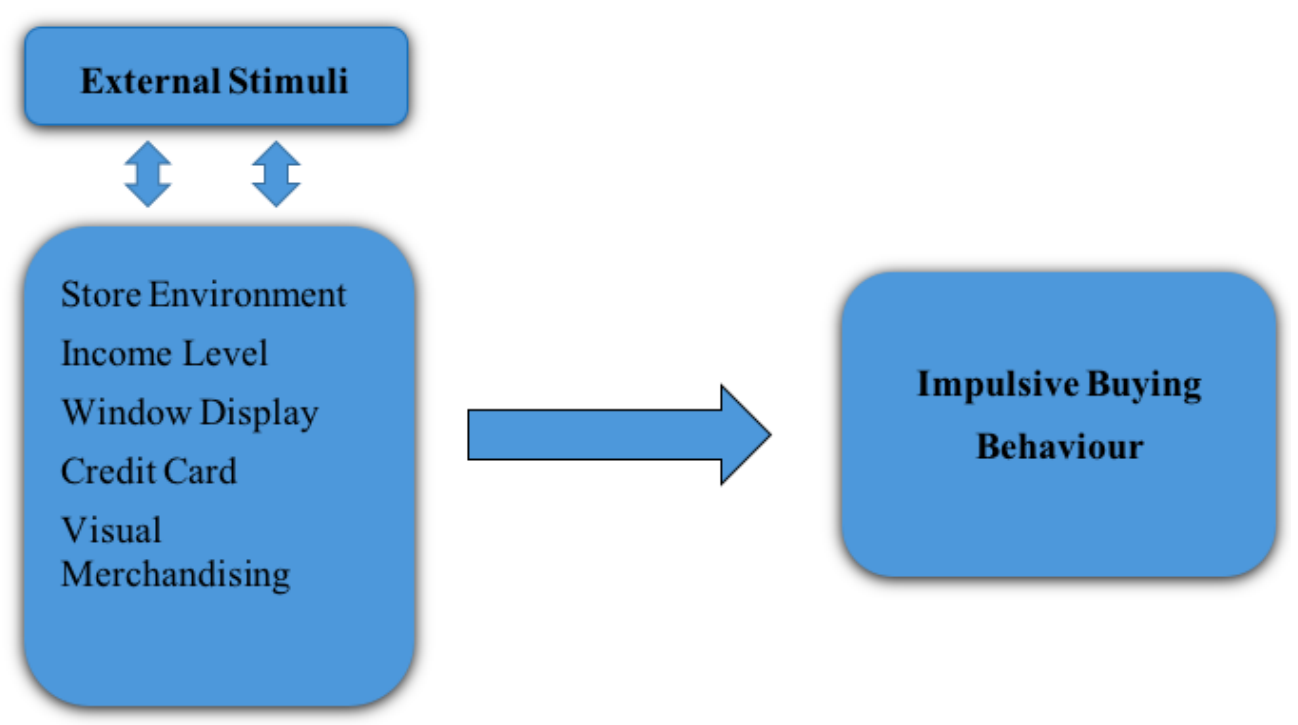

Source: Developed by the researcher.

Figure 1 shows the conceptual framework of the variables for this research. On left hand side we have External stimuli, which is an independent variable and it is further divided into 5 sub-factor such as Store Environment, Income Level, Window Display, Credit 
Card and Visual Merchandising. Impulsive Buying Behaviour (on the right), is a dependent variable for the current study.

\subsection{Hypotheses}

HO1: There is no influence of external factors on impulsive buying behaviour.

HA1: There is influence of external factors on impulsive buying behaviour.

HO2: There is no effect of sub-factors of external stimuli on impulse buying behaviour.

HA2: There is an effect of sub-factors of external stimuli on impulsive buying behaviour.

HO3: There is no difference between male and female impulsive buying behaviour.

HA3: There is difference between male female impulsive buying behaviours.

\subsection{Instruments}

A questionnaire was developed to collect primary data from targeted sample to attain the objective of the study. The questionnaire for the current study is adapted from the studies of Wang and Xiao (2009) and Govindlal (2013). The questionnaire includes two sections; the first section is related the demographics of the respondents, and the second, relates to the attitude of the respondents regarding each sub-factor. The questionnaire is based on the five-step Likert scale, which represents a range of 1 strongly disagrees to 5 strongly agrees and will be analyzed using the SPSS software.

\subsection{Research Approach}

This study is a quantitative study based on the data collected from surveys. Statistical data was gathered and analysed as per the above-mentioned research philosophy. The primary objective of our survey was to understand, analyse and interpret the influence of external factors on impulsive buying behaviour.

\subsection{Population and Sampling}

Bailey (1987) argued that correct sample estimate relies upon the idea of the population and the reason for the research. Sample size measurement has many different approaches, for example: general guidelines, normal size samples from past comparative researches, statistical technique, or even the strategy where the researchers attempts to discover something new (Bryman \& Bell, 2011). For the sampling method, we used convenience sampling technique to select the samples. A total of 350 questionnaires were distributed in stores and we achieved a response rate of $90.2 \%$.

\section{Results and Discussion}

This section relates to the analysis and interpretation of the data collected from the respondents. The data was analysed through SPSS software to minimise human error and to achive more efficient and effective results. The current section includes tables of Descriptive Statistics, Correlation, Regression, Reliability Test, T-test, Cross Tabulations and Frequencies of Gender, Age, Education and Income Level. 
Table 1: Descriptive Statistics

\begin{tabular}{cccccc}
\hline & \multicolumn{5}{c}{ Minim } \\
& $\mathrm{N}$ & um & $\mathrm{m}$ & Mean & Std. Deviation \\
\hline I.B.B & 316 & 2 & 5 & 4.11 & .956 \\
S.E & 316 & 2 & 5 & 3.76 & .861 \\
I.L & 316 & 2 & 5 & 4.41 & .739 \\
W.D & 316 & 2 & 5 & 3.81 & .888 \\
C.C & 316 & 2 & 5 & 4.05 & .857 \\
V.M & 316 & 1 & 4 & 3.54 & .777
\end{tabular}

Descriptive statistics is drawn to show the general characteristics of the data explored. Th data is analyzed with SPSS software to find their mean and standard deviation. Table $1 \mathrm{~h} c$ five columns in which the number of ' $\mathrm{N}$ ' is common, that is 316 which indicates the tot: number of the sample taken. The minimum number indicates 1, which is for visui merchandising and the maximum is 5 which is common in the rest of variables. Noticeabl: the mean of income level was 4.41, which is high as compared to other variables.

Table 2: Correlations

\begin{tabular}{|c|c|c|c|c|c|c|c|}
\hline & & I.B.B & S.E & I.L & W.D & C.C & V.M \\
\hline \multirow{3}{*}{ I.B.B } & Pearson Correlation & 1 & $.743^{* *}$ & $.671^{* * *}$ & $.549^{* *}$ & $.505^{* *}$ & $.736^{* *}$ \\
\hline & Sig. (2-tailed) & & .000 & .000 & .000 & .000 & .000 \\
\hline & $\mathrm{N}$ & 316 & 316 & 316 & 316 & 316 & 316 \\
\hline \multirow{3}{*}{ S.E } & Pearson Correlation & & 1 & $.572^{* *}$ & $.355^{* *}$ & $.430^{* *}$ & $.689^{* *}$ \\
\hline & Sig. (2-tailed) & & & .000 & .000 & .000 & .000 \\
\hline & $\mathrm{N}$ & & 316 & 316 & 316 & 316 & 316 \\
\hline \multirow{3}{*}{ I.L } & Pearson Correlation & & & 1 & $.446^{* *}$ & $.369^{* * *}$ & $.477^{* *}$ \\
\hline & Sig. (2-tailed) & & & & .000 & .000 & .000 \\
\hline & $\mathrm{N}$ & & & 316 & 316 & 316 & 316 \\
\hline \multirow{3}{*}{ W.D } & Pearson Correlation & & & & 1 & $.513^{* *}$ & $.647^{* *}$ \\
\hline & Sig. (2-tailed) & & & & & .000 & .000 \\
\hline & $\mathrm{N}$ & & & & 316 & 316 & 316 \\
\hline \multirow{2}{*}{ C.C } & Pearson Correlation & & & & & 1 & $.607^{* *}$ \\
\hline & Sig. (2-tailed) & & & & & & .000 \\
\hline
\end{tabular}


V.M Sig. (2-tailed)

**. Correlation is significant at the 0.01 level (2tailed).

Table 2 suggest that there is a positive and significant relation between all the independent variables 'Store Environment' (S.E), 'Income Level' (I.L), 'Window Display' (W.D), 'Credit Card' (C.C) and 'Visual Merchandising' (V.M). It further indicates that there is a positive and significant relation between 'Impulsive Buying Behaviour' (I.B.B) and 'Store Environment' (S.E), which has a value of 0.743, whereas the minimum and less significant relation is between 'Store Environment' and 'Window Display' which has a value 0.355 .

Table 2 also indicates that 'Income Level' has a positive and significant relation with 'Impulsive Buying Behaviour' and 'Store Environment' with having a value 0.671 and 0.572 respectively. The correlation value of 'Window Display' with 'Impulsive Buying Behaviour' and 'Income Level' is 0.549 and 0.446 respectively, which also indicates a positive and significant relationship between the variables. The correlation value of 'Credit Card' with 'Impulsive Buying Behaviour', 'Store Environment', 'Income Level' and 'Window Display' is $0.505,0.430,0.369$ and 0.513 respectively, which indicates that there is an optimistic and significant relation between the variables. The correlation value of 'Visual Merchandising' with 'Impulsive Buying Behaviour', 'Store Environment', 'Income Level', 'Window Display', and 'Credit Card' is 0.736, 0.689, 0.477, 0.647 and 0.607 respectively, again it indicates that there is an optimistic and significant relation between the variables.

The value of cronbach alpha was used to check the reliability of the research model. Generally, required value for cronbach alpha should be 0.60 or above (Steinberg et al., 2013).

Table 3: Reliability Statistics

\begin{tabular}{ccc} 
Cronbach's Alpha & $\begin{array}{c}\text { Cronbach's Alpha Based on } \\
\text { Standardized Items }\end{array}$ & N of Items \\
\hline .881 & .882 & 6
\end{tabular}

Table 3 indicates that the value for cronbach alpha is 0.881 which means that the research model is reliable to $88.1 \%$. 
Table 4: Regression Results

\begin{tabular}{ccccccc}
\hline \multirow{2}{*}{ Model } & \multicolumn{2}{c}{$\begin{array}{c}\text { Unstandardized } \\
\text { Coefficients }\end{array}$} & $\begin{array}{c}\text { Standardized } \\
\text { Coefficients }\end{array}$ & $\mathrm{t}$ & Sig. \\
& & $\mathrm{B}$ & Std. Error & Beta & & \\
\hline \multirow{4}{*}{1 (Constant) } & -.713 & .191 & & -3.726 & .000 \\
& S.E & .367 & .052 & .331 & 7.123 & .000 \\
& I.L & .373 & .050 & .289 & 7.462 & .000 \\
& W.D & .110 & .046 & .102 & 2.406 & .017 \\
& C.C & .033 & .043 & .030 & .772 & .441 \\
& V.M & .353 & .067 & .287 & 5.300 & .000 \\
\hline
\end{tabular}

a. Dependent Variable: I.B.B

Correlation indicates the degree of association of one variable with the other but it does not shows the magnitude of the variables. For finding the magnitude of the dependency of dependent variable over independent variables, we used regression model. As per Hypothesis Ha1, there is influence of external stimuli on 'Impulsive Buying Behaviour'. As per hypothesis $\mathrm{Ha} 2$, there is effect of the sub factors of external stimuli on 'Impulsive Buying Behaviour'as the value of beta is positive for all the variables. Table 4 shows the magnitude of each variable towards dependent variable (Impulsive Buying Behaviour). The estimation of Beta for 'Store Environment' is 0.367 which demonstrates that a unit raise in 'Store Environment' will expand the 'Impulsive Buying Behaviour'by 0.367, where the significance is $p=0.000$ and the value of $t=7.123$ which is greater than 2 . This shows a positive association of 'Store Environment' with 'Impulsive Buying Behaviour'. Similarly, the Beta value for 'Income Level' (I.L) is 0.373, which indicates a positive association with significance level of $\mathrm{p}=0.000$ and the value of $\mathrm{t}=7.462$ which is greater then. The maximum value of Beta is for 'Income Level', which means that the respondents are more engaged in 'Impulsive Buying' when their 'Income Level' is high. The 'Beta' value of 'Window Display' (W.D) is 0.110 which indicates a positive association.

This means that a unit increase in 'Window Display' will increase the consumer's 'Impulsive Buying Behaviour' by .110 , with a significance level $\mathrm{p}=0.017$ and the value for $\mathrm{t}=2.462$ which is also greater than 2. The estimation of Beta for 'Credit Card' (C.C) is positive that is .033 which implies that one unit raise in 'Credit Card' will expand 'Impulsive Buying Behaviour' by .033, with significance level of $\mathrm{p}=0.441$ and the $t$-value is $t=.772$ which is less the 2 . This means that credit card has a positive but insignificant relation with 'Impulsive Buying Behaviour'. The Beta value of 'Visual Merchandising' (V.M) is positive i.e. 0.353, which indicates that one unit change in 'Visual Merchandising' will increase the consumer's 'Impulsive Buying Behaviour' by 0.353, where the significance level $\mathrm{p}=0.000$ and the value of $\mathrm{t}=5.300$ which is greater than 2 . This means that 'Visual Merchandising' has a positive and significant association with 'Impulsive Buying Behaviour'. 
Table 5: Model Summary

\begin{tabular}{ccccc}
\hline Model & $\mathrm{R}$ & $\begin{array}{c}\mathrm{R} \\
\text { Square }\end{array}$ & $\begin{array}{c}\text { Adjusted R } \\
\text { Square }\end{array}$ & $\begin{array}{c}\text { Std. Error of the } \\
\text { Estimate }\end{array}$ \\
\hline 1 & $.849^{\mathrm{a}}$ & .722 & .717 & .508 \\
\hline
\end{tabular}

a. Predictors: (Constant), V.M, I.L, C.C, W.D, S.E

Table 5 given above shows that there is a critical impact of independent factors over dependent variable that the estimation of $\mathrm{R}$ square is 0.772 . Which means that the value is greater than the benchmark i.e. 0.60 (Ahmad \& Parmar, 2013). The estimation of $\mathrm{R}$ is 0.849 , which demonstrates that there is a positive connection among the independent variables and the dependent variable.

\section{Cross Tabs}

Table 6: Case Processing Summary

\begin{tabular}{ccccccc}
\hline & \multicolumn{5}{c}{ Cases } \\
\cline { 2 - 7 } & \multicolumn{2}{c}{ Valid } & \multicolumn{2}{c}{ Missing } & \multicolumn{2}{c}{ Total } \\
\cline { 2 - 7 } & $\mathrm{N}$ & Percent & $\mathrm{N}$ & Percent & $\mathrm{N}$ & Percent \\
\hline Gender * Qualification & 316 & $100.0 \%$ & 0 & $.0 \%$ & 316 & $100.0 \%$ \\
\hline
\end{tabular}

Table 6 indicates that all the responses are $100 \%$ valid and there is no any missing value. All the respondents have given their responses very effectively.

Table 7: Gender * Qualification Cross Tabulation

\begin{tabular}{ccccccc}
\hline & & \multicolumn{5}{c}{ Qualification } \\
& & \multicolumn{1}{c}{ <=Bachelors } & Masters & M.S/MPhil & Phd & Total \\
\hline \multirow{3}{*}{ Gender } & Male & 69 & 74 & 51 & 7 & 201 \\
& Female & 20 & 69 & 17 & 9 & 115 \\
\multicolumn{2}{c}{ Total } & 89 & 143 & 68 & 16 & 316 \\
\hline
\end{tabular}

Table 7 indicates that maximum number of respondents has Masters Education. Our respondents were mostly male and the number of females were lesser as compared to male.

Table 8: Case Processing Summary

\begin{tabular}{ccccccr}
\hline & \multicolumn{1}{c}{ Valid } & \multicolumn{2}{c}{ Cases } \\
& \multicolumn{2}{c}{ Missing } & \multicolumn{2}{c}{ Total } \\
\hline & $\mathrm{N}$ & Percent & $\mathrm{N}$ & Percent & $\mathrm{N}$ & Percent \\
Gender * Income & 316 & $100.0 \%$ & 0 & $.0 \%$ & 316 & $100.0 \%$ \\
\hline
\end{tabular}


Table 8 indicates that all the responses are $100 \%$ valid and there is no any missing value. All the respondents have given their responses very effectively.

Table 9: Gender * Income Cross tabulation

\begin{tabular}{|c|c|c|c|c|c|}
\hline \multicolumn{6}{|c|}{ Income } \\
\hline & $\begin{array}{l}\text { Below } \\
30,000\end{array}$ & $\begin{array}{c}30,001- \\
50,000\end{array}$ & $\begin{array}{c}50,001- \\
80,000\end{array}$ & $\begin{array}{l}\text { Above } \\
80,000\end{array}$ & Total \\
\hline Gender & 46 & 58 & 46 & 51 & 201 \\
\hline Female & 15 & 26 & 26 & 48 & 115 \\
\hline Total & 61 & 84 & 72 & 99 & 316 \\
\hline
\end{tabular}

Table 9 indicates that most of our respondents are having their income 80,000 or above, in which we have maximum number of males as compared to females. Also, we have minimum number of females who have income level 30,000 or below, which indicates that both the genders have an impact on Impulsive Buying Behaviour'.

T-Test

Table 10: Paired Samples Test

\begin{tabular}{|c|c|c|c|c|c|}
\hline \multicolumn{4}{|c|}{ Paired Differences } & \multirow[b]{2}{*}{$\mathrm{t}$} & \multirow[b]{2}{*}{$\begin{array}{l}\text { Sig. (2- } \\
\text { tailed) }\end{array}$} \\
\hline $\begin{array}{c}\text { Paired } \\
\text { Sample } \\
\text { Test }\end{array}$ & Mean $\begin{array}{c}\text { Std. } \\
\text { Deviation }\end{array}$ & $\begin{array}{c}\text { Std. Error } \\
\text { Mean }\end{array}$ & $\begin{array}{l}95 \% \text { Confidence } \\
\text { Interval of the } \\
\text { Difference }\end{array}$ & & \\
\hline $\begin{array}{c}\text { Gender }- \\
\text { I.B.B }\end{array}$ & $2.750-.975$ & .055 & $-2.858--2.642$ & 155 & 315 \\
\hline
\end{tabular}

Table 10 indicates the $\mathrm{T}$-test where the value of $\mathrm{t}=-50.115$, which means that there is no disagreement or impact of 'gender' on 'Impulsive Buying Behaviour'.

Table 11: Gender

Frequency Percent Valid Percent Cumulative Percent

\begin{tabular}{|c|c|c|c|c|c|}
\hline \multirow[t]{3}{*}{ Valid } & Male & 201 & 63.6 & 63.6 & 63.6 \\
\hline & Female & 115 & 36.4 & 36.4 & 100.0 \\
\hline & Total & 316 & 100.0 & 100.0 & \\
\hline
\end{tabular}

Table 11 indicates that the number of males were more when compared to females as the number of males are 201 and female respondents are 115. 


\section{Graph 1: Gender}

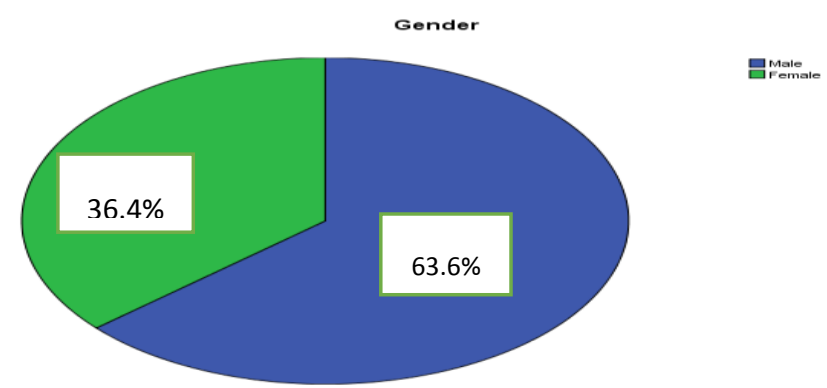

The chart given above indicates that out of total, $63.6 \%$ were male respondents and $36.4 \%$ of female respondents contributed. Which means that males are having more impact on Impulsive Buying Behaviour.

\section{Age Frequency}

Table 12: Age Frequency

\begin{tabular}{cccccc}
\hline & & Frequency & Percent & Valid Percent & Cumulative Percent \\
\hline \multirow{3}{*}{ Valid } & $<=20$ & 9 & 2.8 & 2.8 & 2.8 \\
& $21-30$ & 83 & 26.3 & 26.3 & 29.1 \\
& $31-40$ & 143 & 45.3 & 45.3 & 74.4 \\
& 40 and Above & 81 & 25.6 & 25.6 & 100.0 \\
\hline
\end{tabular}

Table 12 indicates that the maximum number of respondents were at the age from 31-40 whereas the least were at the age 20 or less than 20 . The table also indicates that 83 respondents were at the 21-30 and 81 were at the age 40 and above. The respondents from 31-40 shows the maximum impact on Impulsive Buying Behaviour.

Graph 2: Age

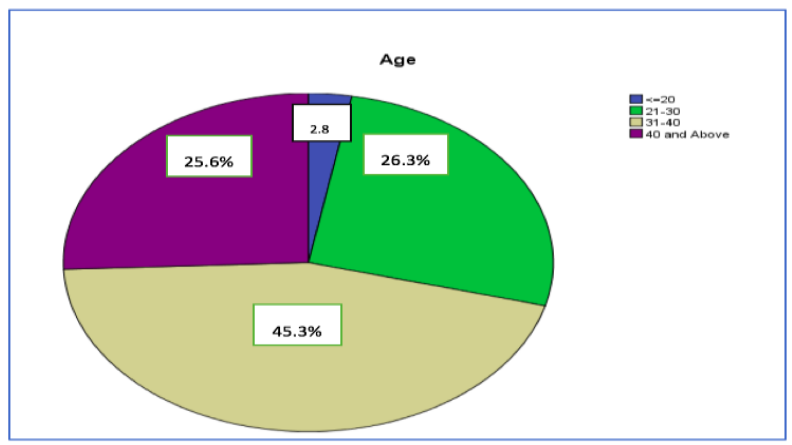

Graph 2 has four groups of the respondents of different ages. The first group is of the age 20 or less which covers $2.8 \%$ of the respondents. The second group is of the age 21-30 which makes $26.3 \%$ of the total. The third group is of the age $31-40$, which is the 
majority respondent group and the fourth group is of the age of 40 and above, which covers $25.6 \%$ of the total. This shows that each of the group has a maximum or minimum impact on consumer's Impulsive Buying Behaviour.

\section{Income Frequency}

Table 13: Income

\begin{tabular}{cccccc}
\hline & Frequency & Percent & $\begin{array}{c}\text { Valid } \\
\text { Percent }\end{array}$ & $\begin{array}{c}\text { Cumulative } \\
\text { Percent }\end{array}$ \\
\hline \multirow{4}{*}{ Valid } & Below 30,000 & 61 & 19.3 & 19.3 & 19.3 \\
& $30,001-50,000$ & 84 & 26.6 & 26.6 & 45.9 \\
& $50,001-80,000$ & 72 & 22.8 & 22.8 & 68.7 \\
& Above 80,000 & 99 & 31.3 & 31.3 & 100.0 \\
& Total & 316 & 100.0 & 100.0 &
\end{tabular}

Table 13 illustrates the categories of the respondents from different income groups. In group 'below 30,000', there were 61respondents. The second group, from 30,001 to 50,000 , has a total of 84 respondents, which makes it the second most responsive group. The third group has income level from 50,001 to 80,000, which has 72 respondents which makes it third most responsive group and the last group has income level above 80,000, which also is the most responsive group in Impulsive Buying Behaviour with a total of 99 respondents.

\section{Graph 3: Income}
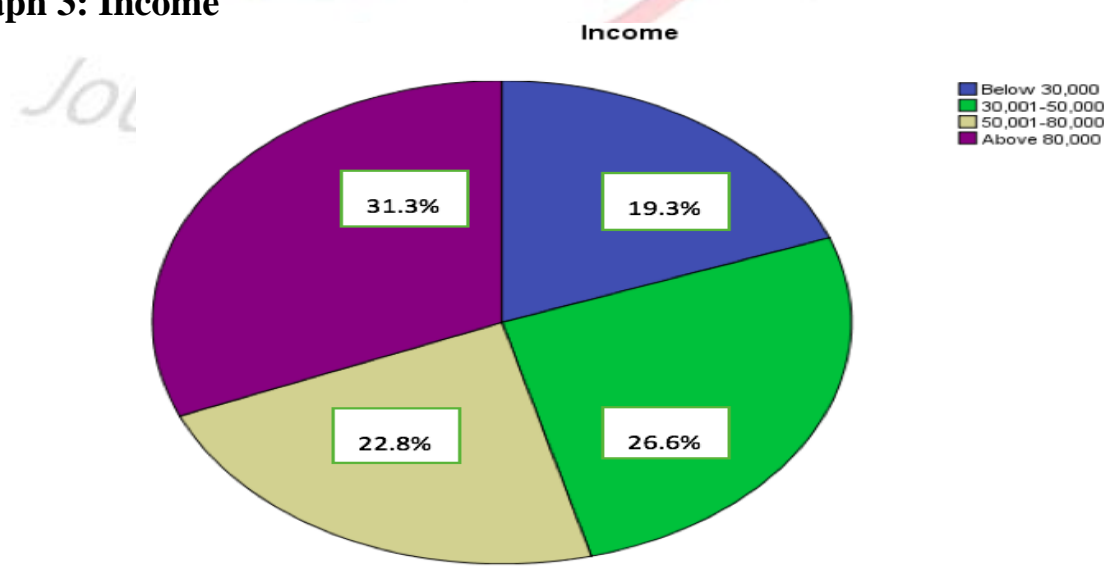

As shown in Graph 3, respondents are classified into four categories regarding their income level. The extreme percentage of the respondents is $31.3 \%$ having income level 80,000 or above and this category has a maximum effect on Impulsive Buying Behaviour. The least level of the respondents is $19.3 \%$. The category has income level 30,000 or below and they have least effect on Impulsive Buying Behaviour. 


\section{Education Frequency}

Table 14: Qualification Frequency

\begin{tabular}{cccccc}
\hline & Frequency & Percent & Valid Percent & $\begin{array}{c}\text { Cumulative } \\
\text { Percent }\end{array}$ \\
\hline \multirow{4}{*}{ Valid } & <=Bachelors & 89 & 28.2 & 28.2 & 28.2 \\
& Masters & 143 & 45.3 & 45.3 & 73.4 \\
& M.S/MPhil & 68 & 21.5 & 21.5 & 94.9 \\
& PhD & 16 & 5.1 & 5.1 & 100.0 \\
& Total & 316 & 100.0 & 100.0 & \\
\hline
\end{tabular}

Table 14 indicates that 89 respondents were having qualification of equal or less than Bachelors and is the second most responsive group. The first most responsive group has 143 respondents who have qualification of Masters. The third group has 68 respondents who have qualification of M.S/M.Phil and the fourth group has 16 respondents who have qualification of Ph.D.

\section{Graph 4: Qualification}
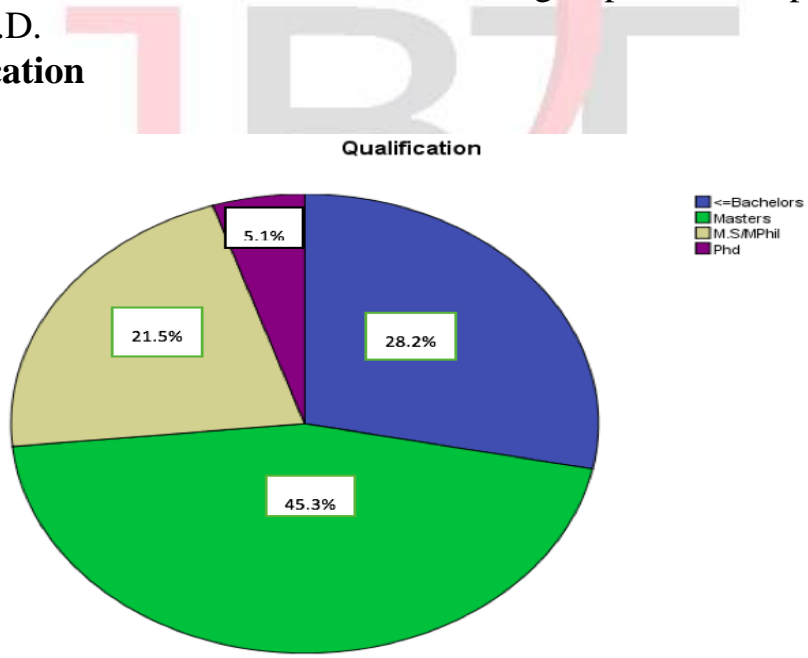

Graph 4 shows that the maximum percentage for the group is $45.3 \%$ that has a qualification of Masters and the minimum percentage for the group is $5.1 \%$, which represents respondents with Ph.D. qualification. This indicates that the respondents having Masters Level of qualification are having more impact in Impulsive Buying Behaviour.

\section{Key Findings and Conclusion}

The aim of current study was to critically examine impulse buying behaviour of customers through the lens of external stimuli. In order to find the results, a questionnaire was developed and distributed among the respondents to collect primary data. The data was then analyzed d interpreted to reach the key findings and conclusion of the study which are mentioned below: 
- The current research suggests that out of all variables, income level has a high influence on impulsive buying behaviour.

- Store environment has the second most influence on impulsive buying behaviour.

- Credit card has a least but insignificant influence on impulsive buying behaviour.

- To find the correlation, we have compared each variable and the results indicates that income level has maximum and significant relation with impulsive buying behaviour with a value of 0.743 .

- Visual Merchandising has the second most positive and significant relation with impulsive buying behaviour with a value of 0.736 .

- The minimum relation of impulsive buying behaviour lies with credit card with a value of 0.505 .

- Respondents with income level 80,000 and higher has a maximum impact on impulsive buying behaviour. The percentage of this group was $31.3 \%$.

- The age group (31-40) has the maximum impact on impulsive buying behaviour as the percentage of this group is the highest i.e. $45.3 \%$. Whereas the second most responsive group is 21-30, which has a percentage of $26.6 \%$.

The current study concludes by arguing that impulsive buying behaviour is promising in Khyber Pakhtoon Khwa, Pakistan. Buyers are mostly attracted towards store environment and window display of the products. Visual merchandising has a positive and significant influence in impulsive buying behaviour. The income level also has a high and significant impact on consumer's impulsive buying behaviour. The use of credit card has a positive but insignificant impact on impulsive buying behaviour. The research study contributes the knowledge to understand the impulsive nature of a buyer. Furthermore, the marketing directors and marketers may find this study useful to understand impulsive purchasing nature of a customer and the significance of key influencing factors. As this research is quantitative in nature, qualitative research can further be conducted and this study could help it.

\section{References}

Abratt, R., \& Goodey, S. D. (1990). Unplanned buying and in-store stimuli in supermarkets. Managerial and Decision Economics, 11(2), 111-121.

Ahmad, R. R., \& Parmar, V. (2013). Factors Influencing Impulse Buying Behaviour. European Journal of Scientific Research, 100(3), 67-79.

Ahmad, S. (2016). Retail in Pakistan - An Overview | Sohail Ahmed | Pulse | LinkedIn. Retrieved September 21, 2017, from https://www.linkedin.com/pulse/retailpakistan-overview-sohail-ahmed

Ampuero, O., \& Vila, N. (2006). Consumer perceptions of product packaging. Journal of Consumer Marketing, 23(2), 100-112.

Applebaum, W. (1951). Studying Customer Behaviour in Retail Stores. Journal of Marketing, 16(2), 172.

Babin, B. J., \& Babin, laurie. (2001). Seeking something different? A model of schema typicality, consumer affect, purchase intentions and perceived shopping value. Journal of Business Research, 54(2), 89-96.

Bailey, K. (1987). Methods of Social Research (3rd ed.). The University of Michigan: 
Free Press.

Bashir, S. (2011). Organizational Cynicism Development and Testing of an Integrated Model A Study of Public Sector Employees in Pakistan, 58-79.

Bayley, G., \& Nancarrow, C. (1998). Impulse purchasing: A qualitative exploration of the phenomenon. Qualitative Market Research: An International Journal, 1(2), 99-114.

Beatty, S. E., \& Elizabeth Ferrell, M. (1998). Impulse buying: Modeling its precursors. Journal of Retailing, 74(2), 161-167.

Bellenger, D. N., \& Korgaonkar, P. K. (1980). Profiling the Recreational Shopper. Journal of Retailing, 56(3), 77-92.

Bhakat, R. S., \& Muruganantham, G. (2013). A Review of Impulse Buying Behaviour. International Journal of Marketing Studies, 5(3), 149.

Bitner, M. J., Ward, J. C., \& Barnes, J. (1992). Measuring the Prototypicality and Meaning of Retail Environments. Journal of Retailing, 68(2), 194-200.

Bryman, A., \& Bell, E. (2011). Business Research Methods (3rd ed.). New York: Oxford University Press.

Butkevičienè, V., Stravinskienè, J., \& Rūtelionienè, A. (2015). Impact of Consumer Package Communication on Consumer Decision Making Process. Engineering Economics, 56(1).

Clover, V. T. (1950). Relative Importance of Impulse-Buying in Retail Stores. Journal of Marketing, 15(1), 66.

Cox, K. (1964). The Responsiveness of Food Sales to Shelf Space Changes in Supermarkets. Journal of Marketing Research, 1(2), 63.

D.W. Rook and Meryl P. Gardner. (1993). In the mood: Impulse buying's affective antecedents (PDF Download Available). Research in Consumer Behaviour, 6(7), $1-28$.

Darden, W. R., Erdem, O., \& Darden, D. K. (1983). A comparison and test of three causal models of patronage intentions. Patronage Behaviour and Retail Management, 4(2), 29-43.

Dittmar Helga, Beattie Jane, F. S. (1995). Gender identity and material symbols: Objects and decision considerations in impulse purchases. Journal of Economic Psychology, 16(3), 491-511.

Gelitz, L. (1995). Financial Engineering: Tools and Techniques to Manage Financial Risk (1st ed.). New York: McGraw Hill.

Ghani, U., \& Ali, F. (2011). An Exploratory Study of the Impulse Buying Behaviour of Urban Consumers in Peshawar. 2010 International Conference on Business and Economics Research, 1, 157-159.

Govindlal, T. K. (2013). A Study of Factors Affecting Impulsive Buying Behaviour by Rural Consumers at the Point of Purchase. Gurgaon.

Han, Y. K., Morgan, G. A., Kotsiopulos, A., \& Kang-Park, J. (1991). Impulse Buying Behaviour of Apparel Purchasers. Clothing and Textiles Research Journal, 9(3), 15-21.

Hoch, S., \& Loewenstein, G. (1991). Time-Inconsistent Preferences and Consumer SelfControl. Journal of Consumer Research. 
Jalees, T. (2009). An Emperical Analysis of Impulsive Buying Behaviour in Pakistan. International Review of Business Research Papers, 5(6), 149-155.

Julie, B., Michael, L., \& Dhruv Grewal. (1992). An experimental approach to making retail store environmental decisions. Journal Of Retailing, 68(4), 445-460.

Kacen, J. J., \& Lee, J. A. (2002). The Influence of Culture on Consumer Impulsive Buying Behaviour. Journal of Consumer Psychology, 12(2), 163-176.

Karbasivar, A., \& Yarahmadi, H. (2011). Evaluating Effective Factors on Consumer Impulse Buying Behaviour. Asian Journal of Business Management Studies, 2(4), 174-181.

Kollat, D. T., \& Willett, R. P. (1969). Customer Impulse Purchasing Behaviour. Journal of Marketing Research, 4(1), 21.

Kristina, M., \& Viltè, A. (2008). Manufacturer and Retailer Brand Acceptance Under Different Levels of Purchase Involvement. Engineering Economics, 3(1), 90-96.

Madhavi, S., \& Leelavati, T. . (2013). Impact of visual merchandising on consumer behaviour towards women apparel. International Journal of Management Research and Business Strategy, 2(4), 319-345.

Mattila, A. S., \& Enz, C. A. (2002). The Role of Emotions in Service Encounters. Journal of Service Research, 4(4), 268-277.

Mills, K. H., Paul, J. E., \& Moormann, K. B. (1995). Applied visual merchandising. Englewood Cliffs, New Jersey: Prentice Hall.

Peck, J., \& Childers, T. L. (2006). If I touch it I have to have it: Individual and environmental influences on impulse purchasing. Journal of Business Research.

Piron, F. (1991). Defining Impulse Purchasing. ACR North American Advances, 18(3), 509-514.

Podoshen, J. S., \& Andrzejewski, S. A. (2012). An Examination of the Relationships Between Materialism, Conspicuous Consumption, Impulse Buying, and Brand Loyalty. The Journal of Marketing Theory and Practice, 20(3), 319-334.

Quartier, K., \& Jan, V. (2009). The Interaction Between Interpreted Space, Mood and Behaviour in Retail Environments: a Conceptual Research Model. IASDR09 'Design: Rigor and Relevance, 2(1), 2-4.

Rettie, R., \& Brewer, C. (2000). The verbal and visual components of package design. Journal of Product \& Brand Management, 9(1), 56-70.

Rook, D. W. (1987). The Buying Impulse. Journal of Consumer Research, 14(2), 189.

Rook, D. W., \& Hoch, S. J. (1985). Consuming Impulses. ACR North American Advances, 12, 23-27.

Saunders, M., Lewis, P., \& Thornhill, A. (2009). Research Methods for Business Students (5th ed.). Edinburgh Gate Harlow Essex, England: Pearson Education Limited, 2009.

Schiffman, L. G., Kanuk, L. L., \& Wisenblit, J. (2010). Consumer behaviour (10th ed.). New Jersy, U.S: Prentice Hall.

Shapiro, D. H. (1992). Adverse effects of meditation: a preliminary investigation of longterm meditators. International Journal of Psychosomatics : Official Publication of the International Psychosomatics Institute, 39(1-4), 62-7.

Silayoi, P., \& Speece, M. (2007). The importance of packaging attributes: a conjoint 
analysis approach. European Journal of Marketing, 41(11/12), 1495-1517.

Steinberg, A. M., Vishnu, P., \& Raheem, A. R. (2013). Factors influencing impulse buying behaviour. European Journal of Scientific Research, 100(3), 1450-216.

Stern, H. (1962). The Significance of Impulse Buying Today. Journal of Marketing, 26(2), 59. https://doi.org/10.2307/1248439

Underwood, R. L., Klein, N. M., \& Burke, R. R. (2001). Packaging communication: attentional effects of product imagery. Journal of Product \& Brand Management, 10(7), 403-422.

Walters, D., \& White, D. (1989). Retail marketing management. Basingstoke, United Kingdom: Macmillan.

Wang, J., \& Xiao, J. J. (2009). Buying behaviour, social support and credit card indebtedness of college students. International Journal of Consumer Studies, $33(1), 2-10$.

Weigend, A. S. (1995). Neural Networks In Financial Engineering - Proceedings Of The Third International Conference On Neural Networks In The Capital Markets. (Y. S, A. Mostafa, A. . Refenes, \& J. Moody, Eds.). London: World Scientific Pub Co Inc, 1996.

Wells, J. D., Parboteeah, V., \& Valacich, J. S. (2011). Online Impulse Buying: Understanding the Interplay between Consumer Impulsiveness and Website Quality. Journal of the Association for Information Systems, 12(1), 32-56.

Wells, L. E., Farley, H., \& Armstrong, G. A. (2007). The importance of packaging design for own-label food brands. International Journal of Retail \& Distribution Management, 35(9), 677-690.

West, C. J. (1951). Results of Two Years of Study into Impulse Buying. Journal of Marketing, 15(3), 362.

Xiao, S. H., \& Nicholson, M. (2013). A Multidisciplinary Cognitive Behavioural Framework of Impulse Buying: A Systematic Review of the Literature. International Journal of Management Reviews, 15(3), 333-356.

$\mathrm{Xu}, \mathrm{Y}$. (2007). Impact of Store Environment on Adult Generation Y Consumers' Impulse Buying. Journal of Shopping Center Research, 14(1), 39-56.

Youn, S., \& Faber, R. J. (2000). Impulse Buying: Its Relation to Personality Traits and Cues. ACR North American Advances, 27(3), 179-185. 